Jurnal Informatika dan Rekayasa Perangkat Lunak (JATIKA)
Vol. 2, No. 3, September 2021, page-page. 390 398
ISSN 2723-3367
E-ISSN 2797.3492
available online at:http://jim.teknokrat.ac.id/index.php/informatika

\title{
SISTEM PAKAR DIAGNOSA PENYAKIT DAN HAMA PADA TANAMAN JAGUNG MENGGUNAKAN METODE NAIVE BAYES
}

\author{
Bayu Bastiyan Suherman \\ Universitas Teknokrat Indonesia \\ bayu_bastiyan@teknokrat.ac.id
}

Published: 30 September 2021

\begin{abstract}
Corn is one of the leading agricultural commodities that can be used as a staple plant other than rice. Constraints faced by corn farmers include the lack of information about diseases that attack the corn plants, which causes less productivity. In this study a system was developed that can automatically detect disease that attacks corn plants so that preventive measures can be taken to prevent corn plants from dying. Expert systems are designed to solve certain problems by imitating the work of experts. In addition, this expert system also helps farmers who are experiencing problems regarding diseases and pests and their solutions without relying on an expert. The method used is the Naive Bayes method, Naive Bayes is a method used to predict probabilities and has several characteristics that are istitively in accordance with the way of thinking of an expert and accompanied by a strong mathematical basis. From the tests carried out with diagnoses obtained from the comparison between the results of expert diagnoses and the diagnosis of the system to diagnose diseases and pests in corn plants is $90 \%$.
\end{abstract}

Keywords: Diet Guide, UXD, Blood Type, Android.

\begin{abstract}
Abstrak
Jagung merupakan salah satu komoditas unggulan pertanian yang dapat digunakan sebagai tanaman pokok selain padi. Kendala yang dihadapi oleh para petani jagung diantaranya yaitu minimnya informasi tentang penyakit yang menyerang tanaman jagung sehingga menyebabkan produktivitas kurang. Pada penelitian ini dibangun sebuah sistem yang dapat melakukan deteksi otomatis tentang penyakit yang menyerang tanaman jagung sehingga dapat dilakukan tindakan-tindakan preventif untuk mencegah tanaman jagung mengalami kematian. Sistem pakar dirancang agar dapat menyelesaikan suatu permasalahan tetentu dengan meniru kerja dari para ahli. Selain itu dengan sistem pakar ini juga pada membantu para petani yang tengah mengalami permasalahan mengenai penyakit dan hama beserta solusinya tanpa bergantung terhadap seorang pakar. Metode yang digunakan adalah metode Naive Bayes, Naive Bayes merupakan metode yang digunakan memprediksi probabilitas dan memeliki beberapa karakteristik yang secara istutitif sesuai dengan cara berfikir seorang pakar dan disertai dasar matematika yang kuat. Dari pengujian yang dilakukan dengan diagnosa yang diperoleh dari perbandingan antar hasil diagnosa pakar dengan diagnosa sistem untuk diagnosa penyakit dan hama pada tanaman jagung adalah sebesar $90 \%$.
\end{abstract}

Kata Kunci: Panduan Diet, UXD, Golongan Darah, Android.

To cite this article:

Bayu Bastiyan Suherman. (2021). SISTEM PAKAR DIAGNOSA PENYAKIT DAN HAMA PADA TANAMAN JAGUNG MENGGUNAKAN METODE NAIVE BAYES. Jurnal Informatika dan Rekayasa Perangkat Lunak, Vol(2) No(3), 390-398.

\section{PENDAHULUAN}

Jagung merupakan salah satu komoditas unggulan pertanian dari sub sektor tanaman pangan yang multi guna dan bernilai strategis untuk dikembangkan. Pada saat ini, jagung tidak hanya dimanfaatkan untuk bahan pangan (food) saja tetapi juga untuk pakan ternak (feed), dan juga bahan bakar (fuel). Jumlah produksi, produktivitas dan harga jagung selalu mengalami fluktuasi karena pengaruh jumlah permintaan dan penawaran 
yang selalu berubah-ubah. Tingginya permintaan jagung di pasar domestik merupakan salah satu peluang bagi Indonesia untuk menyeimbangkan antara jumlah permintaan dan penawaran jagung. Adapun cara yang dapat ditempuh untuk mewujudkan keseimbangan permintaan dan penawaran jagung domestik adalah dengan memproduksi jagung sendiri di dalam negeri dengan menggunakan sumber daya domestik atau dengan melakukan impor jagung dari negara lain.

Tanaman jagung berpotensi terkena serangan hama maupun penyakit yang dapat menyerang kapan saja. Beberapa penyakit yang menyerang tanaman jagung antara lain adalah Hawar Daun, Busuk Pelapah, Bulai, Busuk Tongkol, dan masih banyak lainnya. Penyakit bulai pada jagung sejak lama dirasa menimbulkan kerugian cukup besar, sehingga banyak dikenal diantara para petani. Kerugian akibat penyakit bulai pada jagung sangat bervariasi. Petak-petak tertentu dapat menderita kerugian $90 \%$.

sistem pakar (Expert system) adalah sistem yang berusaha mengadopsi pengetahuan manusia ke komputer, agar komputer dapat menyelesaikan masalah seperti yang biasa dilakukan oleh para ahli (Handoko \& Neneng, 2021; Sulistiani \& Muludi, 2018). Sistem pakar yang baik dirancang agar dapat menyelesaikan suatu permasalahan tertentu dengan meniru kerja dari para ahli. Dengan sistem pakar ini dapat membantu dalam menyelesaikan masalah yang cukup rumit yang sebenarnya hanya dapat diselesaikan dengan bantuan para ahli. Selain itu dengan sistem pakar ini juga pada membantu para petani yang tengah mengalami permasalahan mengenai penyakit dan hama beserta solusinya tanpa bergantung terhadap seorang pakar (Alita et al., 2021; Eka et al., 2020; Napianto et al., 2019; Pebrianto et al., 2020).

Metode Naive Bayes merupakan metode yang digunakan memprediksi probabilitas. Sedangkan klasifikasi Bayes adalah klasifikasi statistik yang dapat memprediksi kelas suatu anggota probabilitas. Untuk klasifikasi Bayes sederhana yang lebih dikenal sebagai naïve Bayesian Classifier dapat diasumsikan bahwa efek dari suatu nilai atribut sebuah kelas yang diberikan adalah bebas dari atribut-atribut lain (Gunawan \& Fernando, 2021; Wibisono et al., 2020). Naïve Bayes Classifier merupakan sebuah metoda klasifikasi yang berakar pada teorema Bayes. Ciri utama dari Naïve Bayes Classifier ini adalah asumsi yang sangat kuat (naif) akan independensi dari masing-masing kondisi/kejadian. Naive Bayes didasarkan pada asumsi penyederhanaan bahwa nilai atribut secara kondisional saling bebas jika diberikan nilai output. Dengan kata lain, diberikan nilai output, probabilitas mengamati secara bersama adalah produk dari probabilitas individu. Keuntungan penggunaan Naive Bayes adalah bahwa metode ini hanya membutuhkan jumlah data pelatihan (Training Data) yang kecil untuk menentukan estimasi paremeter yang diperlukan dalam proses pengklasifikasian. Naive Bayes sering bekerja jauh lebih baik dalam kebanyakan situasi dunia nyata yang kompleks dari pada yang diharapkan.

Penelitian dilakukan karena Jagung merupakan salah satu komoditas unggulan pertanian dari sub sektor tanaman pangan yang multi guna dan bernilai strategis untuk dikembangkan. Pada saat ini, jagung tidak hanya dimanfaatkan untuk bahan pangan (food) saja tetapi juga untuk pakan ternak (feed), dan juga bahan bakar (fuel). Jumlah produksi, produktivitas dan harga jagung selalu mengalami fluktuasi karena pengaruh jumlah permintaan dan penawaran yang selalu berubah-ubah. Tingginya permintaan jagung di pasar domestik merupakan salah satu peluang bagi Indonesia untuk menyeimbangkan antara jumlah permintaan dan penawaran jagung. Adapun cara yang dapat ditempuh untuk mewujudkan keseimbangan permintaan dan penawaran jagung domestik adalah dengan memproduksi jagung sendiri di dalam negeri dengan menggunakan sumber daya domestik atau dengan melakukan impor jagung dari negara lain. Penyakit tanaman jagung adalah salah satu penyebab tidak maksimalnya produksi jagung, bahkan penyakit bulai dapat menyebabkan kegagalan panen hingga 90\%, keberadaan pakar akan sangat membantu dalam hal menangani permasalahan hama dan penyakit yang menyerang tanaman jagung dengan cara mengidentifikasi gejala yang dialami dan menyimpulkan hama atau penyakit apa yang menyerang serta memberikan informasi untuk menangani permasalahan. Metode Naive Bayes merupakan metode yang digunakan memprediksi probabilitas. Sedangkan klasifikasi Bayes adalah klasifikasi statistik yang dapat memprediksi kelas suatu anggota probabilitas. Untuk klasifikasi Bayes sederhana yang lebih dikenal sebagai Naïve Bayesian Classifier dapat diasumsikan bahwa efek dari suatu nilai atribut sebuah kelas yang diberikan adalah bebas dari atribut-atribut lain. Variabel yang dibutuhkan dalam penelitian ini adalah gejala-gejala pada daun, batang dan tongkol tanaman jagung. Hasil pengujian penelitian ini menunjukkan semua kebutuhan fungsional valid, akurasi sistem sebesar 96\% dan hasil usability testing dinyatakan sangat baik (Syarifudin et al., 2018).

Penelitian karena banyak nya penyakit pada jagung saat ini dapat membuat petani bingung dalam menentukan ataupun memilih jenis pengobatan yang sesuai dengan penyakit jagung tersebut. Ini yang membuat petani susah mendapatkan hasil karena mereka tidak bisa melakukan pendiagnosaan yang tepat, sehingga tingkat produktifitas menurun. Sistem pakar berbasis komputer dapat digunakan dalam membantu memecahkan masalah dalam hal membantu setiap petani dalam menentukan pilihan pengobatan. Adapun metode yang digunakan dalam mendiagnosa penyakit pada tanaman jagung adalah Metode Bayes, Untuk membuat hasil diagnosa menjadi sangat valid, maka data gejala yang di masukkan oleh seorang administrator / pakar kedalam suatu data penyakit, harus 
lengkap artinya gejala-gejala yang bisa mengarah ke suatu penyakit tersebut harus di masukkan secara lengkap karena kesimpulan hasil diagnosa yang di tampilkan di hitung secara otomatis oleh sistem aplikasi yaitu banyaknya gejala yang dipilih oleh user di bagi dengan banyaknya gejala yang di miliki suatu penyakit (Sihotang, 2018).

Berdasarkan penelitian yang pernah dilakukan para penelit sebelumnya, penelitian tentang implementasi sistem pakar untuk mendiagnosa penyakit dan hama pada tanaman jagung diharapkan akan memperoleh pengalaman berharga dalam bidang penerapan teknologi di dunia pertanian baik secara teori maupun penerapan lapangan, dengan demikian penelitian ini dimaksudkan untuk merealisasikan sistem pakar metode Naive Bayes dalam aplikasi web yang dapat diakses secara online.

\section{METODE PENELITIAN}

\section{Kerangka Penelitian} berikut.

kerangka pemikiran yang ada, maka kerangka penelitian yang digunakan dapat dilihat pada gambar 1

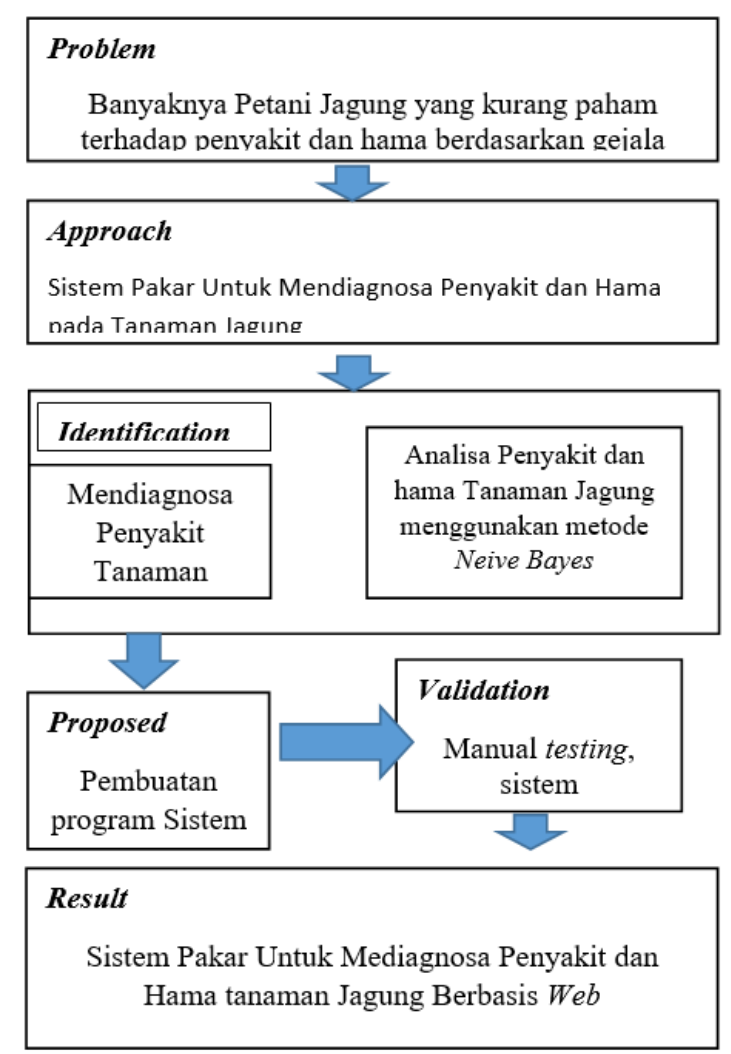

Gambar 1. Kerangka Penelitan

1. Problems (Masalah)

Tahapan penelitian diawali dengan penentuan masalah penelitian, yaitu mengenai kurangnya pengetahuan petani terhadap Penyakit dan Hama pada Tanaman Jagung

2. Approach (Pendekatan)

Pendekatan dalam penelitian adalah cara penulis untuk melakukan pendekatan terhadap hal yang akan diteliti diantaranya solusi dari permasalahan yaitu sistem pakar untuk mendiagnosa Penyakit dan Hama Tanaman Jagung

3. Identification (Identifikasi)

Identifikasi yang dimaksud adalah berkaitan dengan variabel yang akan digunakan dalam penelitian ini mengenai metode yang digunakan yaitu Naive Bayes, sehingga hasil yang akan disajikan sesuai dengan tujuan yang diharapkan yaitu mendiagnosis Penyakit dan Hama Tanaman Jagung 
4. Proposed (Usulan)

Usulan yang disajikan dalam penelitian ini adalah membuat program sistem pakar diagnosa Penyakit dan Hama berbasis web agar dapat di akses secara online oleh pengguna.

5. Validation (Pengujian)

Pengujian dilakukan dengan menggunakan perhitungan Manual, Microsoft Exceel dan sistem.

6. Result (Hasil)

Penerapan sistem pakar untuk mendiagnosa Penyakit dan Hama Tanaman Jagung berbasis web

\section{Teknik Pengumpulan Data}

1. Wawancara

Dalam metode wawancara dilakukan secara langsung untuk melakukan tanya-jawab kepada kepada petani di Lingkungan Totokaton, Kelurahan Adipuro, Kecamatan Trimurjo.

2. Observasi

Melakukan pengamatan langsung terhadap objek yang akan diteliti dan mengamati alur atau proses untuk mendapatkan data yang akurat di Lingkungan Totokaton, Kelurahan Adipuro, Kecamatan Trimurjo.

3. Dokumentasi

Studi Pustaka dilakukan dengan cara membaca, mengutip dan membuat catatan yang bersumber pada bahan-bahan pustaka yang mendukung dan berkaitan dengan penelitian ini khususnya dalam pengembangan Sistem Pakar. Selanjutnya dengan cara mempelajari dan memahami jurnal dan buku-buku referensi, yang berhubungan dengan masalah yang akan dibahas, Hal ini dimaksudkan agar memiliki landasan teori yang kuat (Alfiah \& Damayanti, 2020; Puspaningrum et al., 2020; Septilia et al., 2020).

\section{Metode Analisis Sistem / Usecase Diagram}

Use Case diagram merupakan pemodelan untuk kegiatan pada sistem yang akan dibuat (Setiawansyah et al., 2021; Sulistiani, Sulistiyawati, et al., 2021). Sistem memiliki dua aktor yaitu Admin dan User. Use Case Diagram dapat dilihat pada gambar berikut

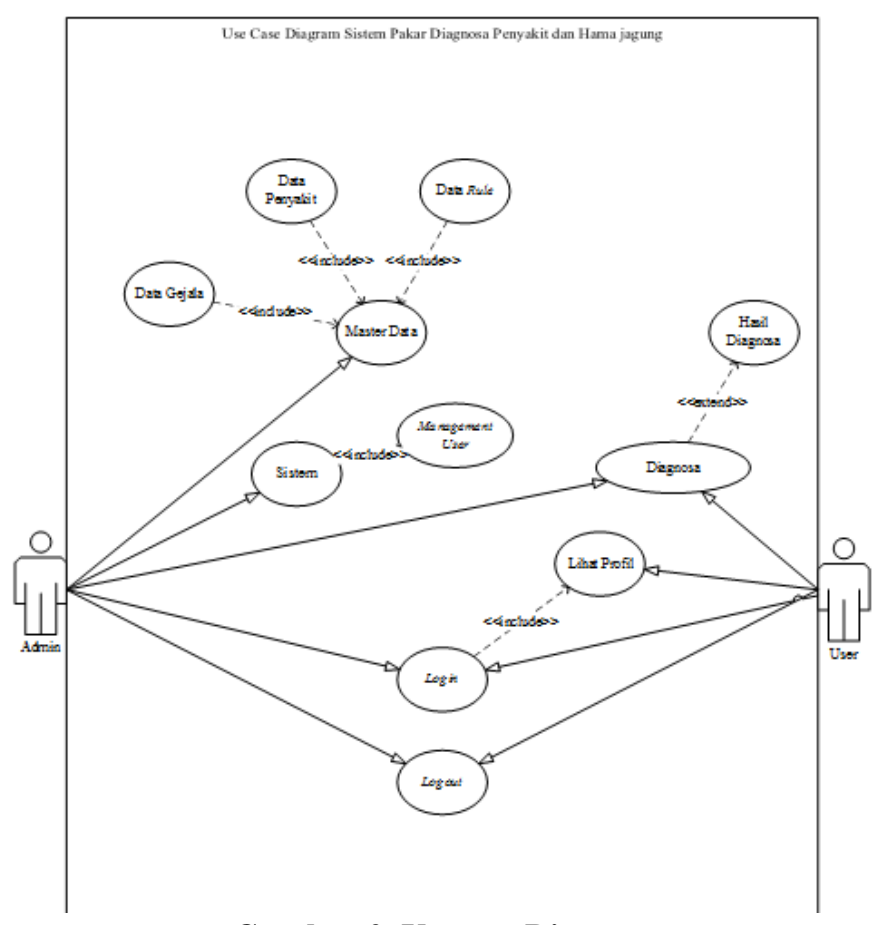

Gambar 2. Usecase Diagram

\section{HASIL DAN PEMBAHASAN}


Implementasi merupakan penerapan cara kerja sistem berdasarkan hasil analisa dan juga perancangan yang telah dibuat sebelumnya kedalam suatu behasa pemrograman tertentu. Tahap ini merupakan tahap dimana aplikasi siap untuk dioperasikan. Dibawah ini terdapat tampilan-tampilan dari sistem pakar untuk mendiagnosa penyakit dan hama pada tanaman Jagung menggunakan metode naive bayes.

\section{Tampilan Menu Diagnosa User}

Form menu diagnosa, user atau pengguna akan diberikan pilihan sejumlah gejala penyakit dan hama yang terjadi pada tanaman jagung. Gejala penyakit dan hama ini merupakan gejala dari seluruh penyakit yang telah direkomendasikan oleh pakar dan buku dibidangnya. User nantinya diharuskan memilih beberapa gejala kerusakan yang telah disediakan oleh sistem. Pemilihan gejala dengan cara menceklis kotak yang telah disediakan, setelah memilih gejala penyakit klik tombol proses, maka sistem akan memproses gejala-gejala dan menghitung menggunakan algoritma naive bayes. ketika user atau pengguna menginput gejala gejala
1. pucuk daun layu
2. adanya bekas gigitan pada batangnya
3. tanaman menjadi layu
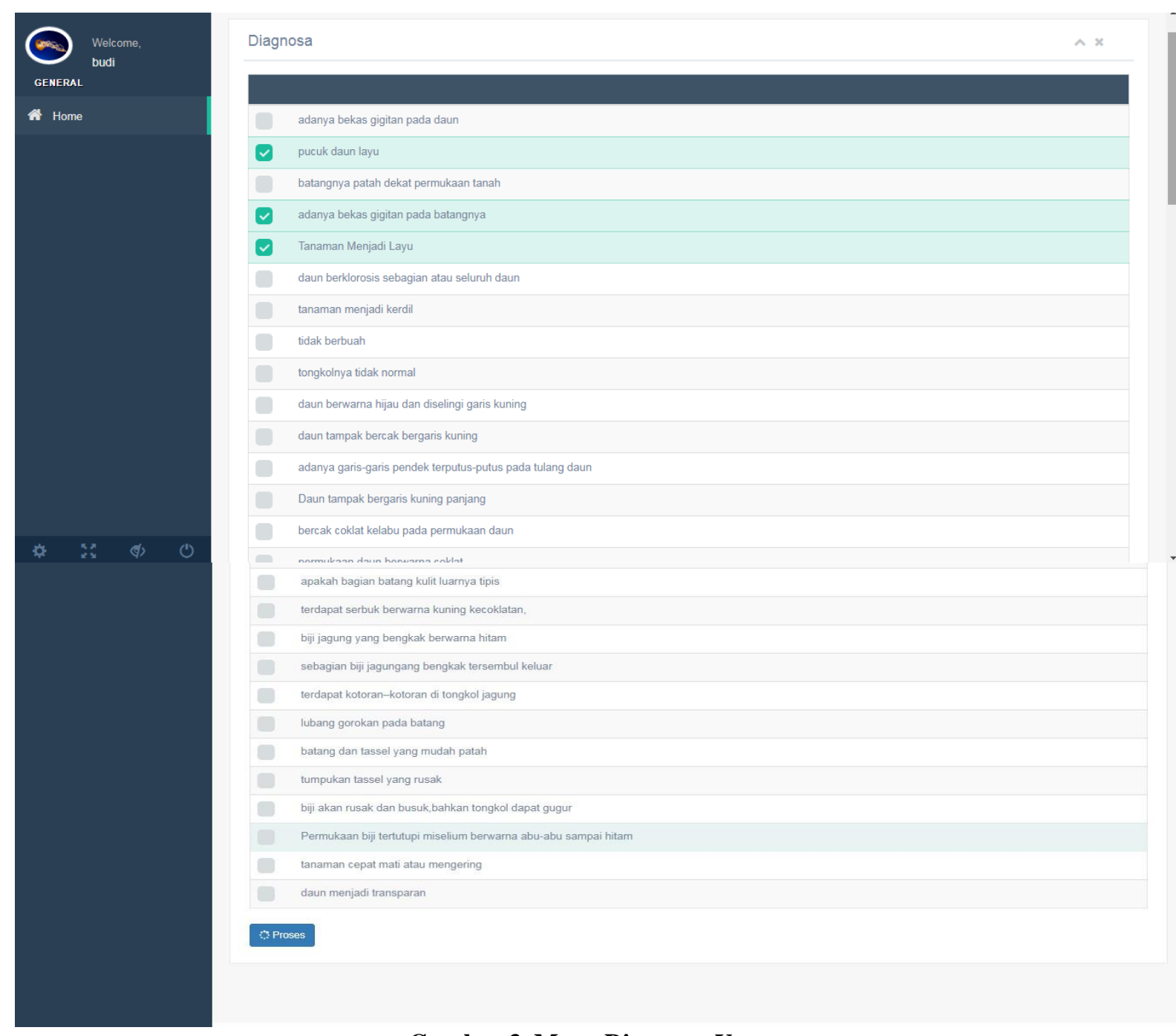

\section{Gambar 3. Menu Diagnosa User}

\section{Tampilan Menu Hasil Diagnosa User}

Tampilan hasil diagnosa penyakit dan hama serta solusi pada sistem pakar mendiagnosa penyakit dan hama pada tanaman jagung akan menampilkan hasil diagnosa yang telah dipilih oleh user dan menampilkan jenis 
penyakit atau hama. Hasil diagnosa akan diperkuat dengan tingkat persentase probabilitas dari penggunaan metode Naive Bayes. Tampilan hasil diagnosa yang telah d pilih user atau pengguna yaitu teserang penyakit hama belalang dengan pesetase $1,75 \%$
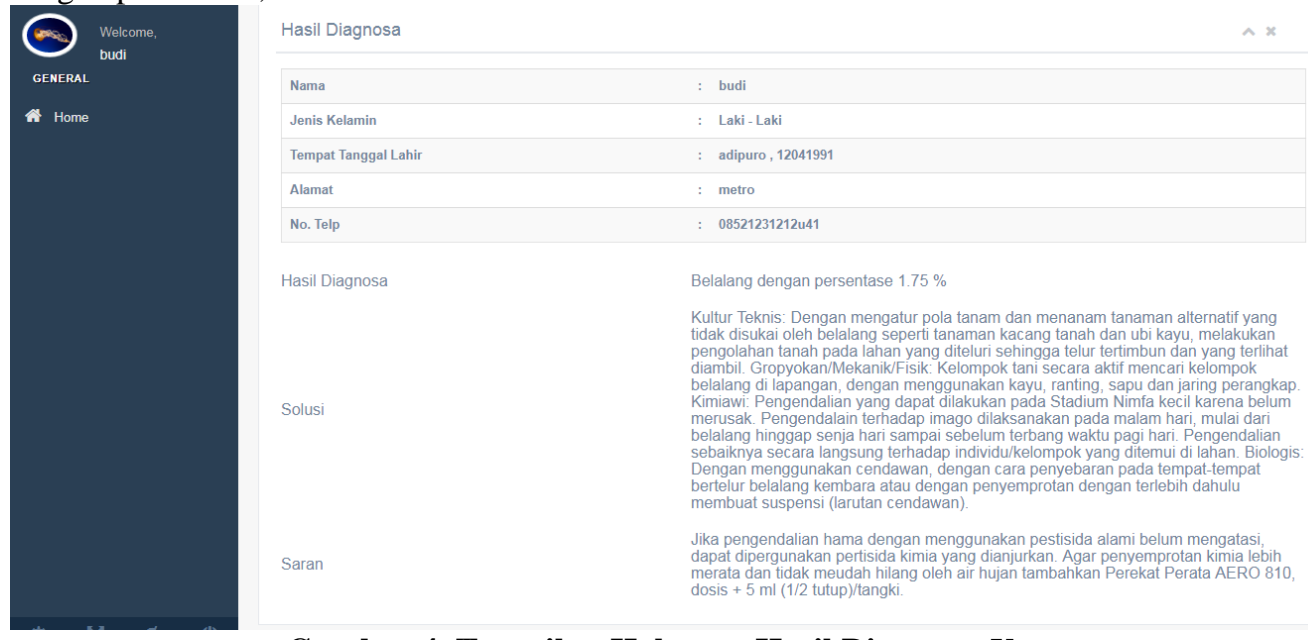

Gambar 4. Tampilan Halaman Hasil Diagnosa User

\section{Validasi Kelayakan Sistem Pakar Untuk Diagnosa Penyakit Dan Hama Pada Tanaman Jagung}

Validasi Sistem dilakukan sebagai proses pengujian kinerja atau tingkat keberhasilan sistem. Proses validasi sistem dilakukan setelah desain dan implementasi terhadap system (Ahdan \& Setiawansyah, 2020; Pasaribu et al., 2019; Sulistiani, Darwis, et al., 2020). Proses validasi terhadap sistem dengan memasukkan data uji kedalam sistem. Hal ini dilakukan dengan tujuan untuk mengetahui sejauh mana sistem memiliki tingkat keberhasilan, berdasarkan data uji yang dimasukkan. Pada penelitian ini tingkat keberhasilan sistem ditentukan berdasarkan ketepatan diagnosis (Maulida et al., 2020; Megawaty \& Putra, 2020; Saputra \& Borman, 2020; Sulistiani, Octriana, et al., 2020; Sulistiani, Yuliani, et al., 2021). Perhitungan ketepatan diagnosis diperoleh dari perbandingan antara hasil diagnosis sistem yang sama dengan diagnosis pakar dibandingkan dengan banyaknya data yang diujikan dakalikan $100 \%$

Tabel 1. Validasi Sistem Dengan Pakar

\begin{tabular}{|c|c|c|c|}
\hline No & Gejala & $\begin{array}{l}\text { Identifikasi } \\
\text { Pakar }\end{array}$ & $\begin{array}{l}\text { Identifikasi } \\
\text { Sistem }\end{array}$ \\
\hline \multirow{3}{*}{1} & Adanya Bekas Gigitan Pada Daun & \multirow{3}{*}{ Belalang } & \multirow{3}{*}{ Belalang } \\
\hline & Akar Rusak Karena Gigitan Lundi & & \\
\hline & Adanya Bekas Gigitan Pada Batangnya & & \\
\hline \multirow{4}{*}{2} & Tanaman Menjadi Kerdil & \multirow{4}{*}{ Penyakit Bulai } & \multirow{4}{*}{ Bulai } \\
\hline & Tidak Berbuah & & \\
\hline & Tongkolnya Tidak Normal & & \\
\hline & Tanaman Menjadi Layu & & \\
\hline \multirow{3}{*}{3} & Batangnya Patah Dekat Permukaan Tanah & \multirow{3}{*}{ Ulat Grayak } & \multirow{3}{*}{ Ulat Grayak } \\
\hline & Adanya Bekas Gigitan Pada Batangnya & & \\
\hline & Daun Tanaman Muda Rusak & & \\
\hline \multirow{3}{*}{4} & $\begin{array}{l}\text { Daun Berwarna Hijau Dan Diselingi Garis } \\
\text { Kuning }\end{array}$ & \multirow{3}{*}{ Virus Mozaik Kerdil } & \multirow{3}{*}{ Virus Mozaik Kerdil } \\
\hline & $\begin{array}{c}\text { Daun Bagian Bawah Dan Atas Dipegang } \\
\text { Tidak Terasa Adanya Serbuk Spora }\end{array}$ & & \\
\hline & Tanaman Menjadi Kerdil & & \\
\hline \multirow{5}{*}{5} & Batang Busuk & \multirow{5}{*}{$\begin{array}{l}\text { Busuk Batang Dan } \\
\text { Tongkol }\end{array}$} & \multirow{5}{*}{$\begin{array}{l}\text { Busuk Tongkol Dan } \\
\text { Batang }\end{array}$} \\
\hline & Apakah Tanaman Mudah Rebah & & \\
\hline & Bagian Atas Layu Dan Mengering & & \\
\hline & Apakah Bagian Batang Kulit Luarnya Tipis & & \\
\hline & Rusaknya Tongkol & & \\
\hline
\end{tabular}




\begin{tabular}{|c|c|c|c|}
\hline \multirow{3}{*}{6} & $\begin{array}{c}\text { Biji Akan Rusak Dan Busuk,Bahkan Tongkol } \\
\text { Dapat Gugur }\end{array}$ & \multirow{3}{*}{ Penyakit Karat } & \multirow{3}{*}{ Penyakit Karat } \\
\hline & Permukaan Daun Berwarna Coklat & & \\
\hline & $\begin{array}{c}\text { Permukaan Biji Tertutupi Miselium Berwarna } \\
\text { Abu-Abu Sampai Hitam }\end{array}$ & & \\
\hline \multirow{3}{*}{7} & $\begin{array}{c}\text { Adanya Garis-Garis Pendek Terputus-Putus } \\
\text { Pada Tulang Daun }\end{array}$ & \multirow{3}{*}{ Penggerek Batang } & \multirow{3}{*}{ Ulat Grayak } \\
\hline & Tanaman Menjadi Kerdil & & \\
\hline & Daun Tampak Bergaris Kuning Panjang & & \\
\hline \multirow{4}{*}{8} & .Lubang Kecil Pada Daun & \multirow{4}{*}{ Penggerek Batang } & \multirow{4}{*}{ Penggerek Batang } \\
\hline & Tumpukan Tassel Yang Rusak & & \\
\hline & .Lubang Gorokan Pada Batang & & \\
\hline & Batang Dan Tassel Yang Mudah Patah & & \\
\hline \multirow{4}{*}{9} & $\begin{array}{l}\text { Warna Daun Dari Hijau Normal Menjadi } \\
\text { Kekuning-Kuningan }\end{array}$ & \multirow{4}{*}{ Kutu Daun } & \multirow{4}{*}{ Kutu Daun } \\
\hline & Bagian Atas Layu Dan Mengering & & \\
\hline & Daun Tanaman Muda Rusak & & \\
\hline & Daun Tampak Bergaris Kuning Panjang & & \\
\hline \multirow{3}{*}{10} & Rusaknya Tongkol & \multirow{3}{*}{ Penggerek Tongkol } & \multirow{3}{*}{ Penggerek Tongkol } \\
\hline & Ada Ulat Ditongkol Jagung & & \\
\hline & Terdapat Kotoran-Kotoran Di Tongkol Jagung & & \\
\hline \multirow{3}{*}{11} & Daun Menjadi Transparan, & \multirow{3}{*}{ Ulat Grayak } & \multirow{3}{*}{ Ulat Grayak } \\
\hline & Tulang Daun Rusak & & \\
\hline & $\begin{array}{c}\text { Berlubang Bahkan Tinggal Tulang-Tulang } \\
\text { Saja }\end{array}$ & & \\
\hline \multirow{3}{*}{12} & Adanya Bekas Gigitan Pada Daun & \multirow{3}{*}{ Belalang } & \multirow{3}{*}{ Belalang } \\
\hline & Adanya Bekas Gigitan Pada Batangnya & & \\
\hline & Tulang Daun Rusak & & \\
\hline \multirow{5}{*}{13} & Tanaman Menjadi Layu & \multirow{5}{*}{$\begin{array}{l}\text { Wereng Jagung } \\
\text { (Kumbang Tanduk) }\end{array}$} & \multirow{5}{*}{ Penggerek Batang } \\
\hline & Pucuk Daun Layu & & \\
\hline & Tanaman Menjadi Kerdil & & \\
\hline & Daun Tampak Bercak Bergaris Kuning & & \\
\hline & Daun Tampak Bergaris Kuning Panjang & & \\
\hline \multirow{3}{*}{14} & Permukaan Daun Berwarna Coklat & & \\
\hline & $\begin{array}{l}\text { Terdapat Serbuk Berwarna Kuning } \\
\text { Kecoklatan, }\end{array}$ & Penyakit Karat & Penyakit Karat \\
\hline & Terdapat Titik Merah Kecoklatan Seperti Karat & & \\
\hline & Biji Jagung Yang Bengkak Berwarna Hitam & & \\
\hline 15 & Terdapat Titik Merah Kecoklatan Seperti Karat & Penyakit Gosong & Penvakit Karat \\
\hline 15 & Adanya Bekas Gigitan Pada Batangnya & Bengkak & Penyakit Karat \\
\hline & Tongkol Pembungkus Rusak & & \\
\hline & Akar Rusak Karena Gigitan Lundi & & \\
\hline 16 & Tanaman Menjadi Layu & Penggerek Batang & Penggerek Batang \\
\hline & Daun Tampak Bercak Bergaris Kuning & & \\
\hline 17 & $\begin{array}{c}\text { Daun Bagian Bawah Dan Atas Dipegang } \\
\text { Tidak Terasa Adanya Serbuk Spora }\end{array}$ & & \\
\hline 17 & Tanaman Menjadi Kerdil & Virus Mozaik Kerdil & Virus Mozaik Kerdil \\
\hline & Batang Busuk & & \\
\hline & $\begin{array}{c}\text { Adanya Garis-Garis Pendek Terputus-Putus } \\
\text { Pada Tulang Daun }\end{array}$ & & \\
\hline 18 & Tanaman Menjadi Kerdil & Penyakit Bulai & Ulat Grayak \\
\hline & Batang Busuk & & \\
\hline
\end{tabular}




\begin{tabular}{|c|c|c|c|}
\hline & & & \\
\hline \multirow{4}{*}{19} & Apakah Bagian Batang Kulit Luarnya Tipis & \multirow{4}{*}{$\begin{array}{l}\text { Busuk Batang Dan } \\
\text { Tongkol }\end{array}$} & \multirow{4}{*}{$\begin{array}{l}\text { Busuk Batang Dan } \\
\text { Tongkol }\end{array}$} \\
\hline & Rusaknya Tongkol & & \\
\hline & $\begin{array}{l}\text { Terdapat Serbuk Berwarna Kuning } \\
\text { Kecoklatan, }\end{array}$ & & \\
\hline & $\begin{array}{c}\text { Biji Akan Rusak Dan Busuk,Bahkan Tongkol } \\
\text { Dapat Gugur }\end{array}$ & & \\
\hline \multirow{3}{*}{20} & Adanya Bekas Gigitan Pada Batangnya & \multirow{3}{*}{ Kutu Daun } & \multirow{3}{*}{ Kutu Daun } \\
\hline & Daun Tanaman Muda Rusak & & \\
\hline & Tanaman Menjadi Layu & & \\
\hline
\end{tabular}

Tabel 2. Persentasi Validasi

\begin{tabular}{|c|c|}
\hline Presentasi Nilai & Klarifikasi \\
\hline $70-100$ & Layak \\
\hline $24-69$ & Kurang layak / Perbaiki \\
\hline $0-33$ & Tidak Layak \\
\hline
\end{tabular}

Jumlah diagnosa yang diuji $\quad: 20$

Jumlah jawaban yang sesuai $\quad: 18$

Jumlah jawaban yang tidak sesuai $\quad: 2$

Penilaian kelayakan $\quad: 18 / 20 \times 100 \%=90 \%$

Berdasarkan pengujian yang dilakukan dengan ketepatan diagnosa yang diperoleh dari perbandingan antar hasil diagnosa pakar dengan diagnosa sistem adalah dengan presentase 90\%, sistem dapat klarifikasi layak untuk digunakan.

\section{SIMPULAN}

Berdasarkan penelitian dan pembahasan yang sudah dilakukan maka dapat disimpulkan sebagau berikut Sistem pakar ini dirancang dengan menerapkan metode Naive Bayes, dimana gejala-gejala penyakit dan hama pada tanaman jagung dipilih oleh user kemudian diproses yang nantinya hasil output yaitu jenis penyakit atau hama dan solusi. Sedangkan yang menentukan nilai peobabilitas di tiap gejala adalah seorang pakar. Dari hasil pengujian terhadap Aplikasi Sistem Pakar yang di bangun, sistem pakar dapat menyeles aikan masalah yaitu bisa menampilkan hasil diagnosa dengan cepat dan tepat berdasarkan gejala-gejala yang di masukkan oleh user. Sistem pakar diagnosa penyakit dan hama pada tenaman jagung menggunakan metode Nä̈ve Bayes dapat diimplementasikan dengan 3 proses utama yaitu menghitung nilai prior atau peluang penyakit, menghitung likelihood berdasarkan peluang gejala terhadap penyakit, serta menghitung posterior yang diperoleh dari perkalian antara prior dan likelihood. Nilai posterior tertinggi akan diambil sebagai keputusan akhir sistem.

\section{REFERENSI/DAFTAR PUSTAKA}

Ahdan, S., \& Setiawansyah, S. (2020). Pengembangan Sistem Informasi Geografis Untuk Pendonor Darah Tetap di Bandar Lampung dengan Algoritma Dijkstra berbasis Android. Jurnal Sains Dan Informatika: Research of Science and Informatic, 6(2), 67-77.

Alfiah, A., \& Damayanti, D. (2020). Aplikasi E-Marketplace Penjualan Hasil Panen Ikan Lele (Studi Kasus: Kabupaten Pringsewu Kecamatan Pagelaran). Jurnal Teknologi Dan Sistem Informasi, 1(1), 111-117.

Alita, D., Sari, I., Isnain, A. R., \& Styawati, S. (2021). Penerapan Naïve Bayes Classifier Untuk Pendukung Keputusan Penerima Beasiswa. Jurnal Data Mining Dan Sistem Informasi, 2(1), 17-23.

Eka, S., Putri, Y., \& Surahman, A. (2020). PENERAPAN MODEL NAIVE BAYES UNTUK MEMPREDIKSI POTENSI PENDAFTARAN SISWA DI SMK TAMAN SISWA TELUK. 1(1), 81-86.

Gunawan, I., \& Fernando, Y. (2021). SISTEM PAKAR DIAGNOSA PENYAKIT KULIT PADA KUCING MENGGUNAKAN METODE NAIVE BAYES BERBASIS WEB. Jurnal Informatika Dan Rekayasa Perangkat Lunak, 2(2).

Handoko, M. R., \& Neneng, N. (2021). SISTEM PAKAR DIAGNOSA PENYAKIT SELAMA KEHAMILAN MENGGUNAKAN METODE NAIVE BAYES BERBASIS WEB. Jurnal Teknologi Dan Sistem Informasi, 2(1), 5058.

Maulida, S., Hamidy, F., \& Wahyudi, A. D. (2020). Monitoring Aplikasi Menggunakan Dashboard untuk Sistem Informasi Akuntansi Pembelian dan Penjualan (Studi Kasus: UD Apung). Jurnal Tekno Kompak, 14(1). 
Megawaty, D. A., \& Putra, M. E. (2020). APLIKASI MONITORING AKTIVITAS AKADEMIK MAHASISWA PROGRAM STUDI INFORMATIKA UNIVERSITAS XYZ BERBASIS. 1(1), 65-74.

Napianto, R., Rahmanto, Y., \& Lestari, R. I. B. D. O. (2019). Software Development Sistem Pakar Penyakit Kanker Pada Rongga Mulut Berbasis Web. Dalam Seminar Nasional Pengaplikasian Telematika (Sinaptika 2019), Jakarta.

Pasaribu, A. F. O., Darwis, D., Irawan, A., \& Surahman, A. (2019). Sistem Informasi Geografis untuk Pencarian Lokasi Bengkel Mobil di Wilayah Kota Bandar Lampung. Jurnal Tekno Kompak, 13(2), 1-6.

Pebrianto, R., Nugraha, S. N., \& Gata, W. (2020). Perancangan Sistem Pakar Penentuan Jenis Kulit Wajah Menggunakan Metode Certainty Factor. 5(April), 83-93.

Puspaningrum, A. S., Susanto, E. R., \& Sucipto, A. (2020). Penerapan Metode Forward Chaining Untuk Mendiagnosa Penyakit Tanaman Sawi. INFORMAL: Informatics Journal, 5(3), 113-120.

Saputra, A. D., \& Borman, R. I. (2020). Sistem Informasi Pelayanan Jasa Foto Berbasis Android (Studi Kasus: Ace Photography Way Kanan). Jurnal Teknologi Dan Sistem Informasi, 1(2), 87-94.

Septilia, H. A., Parjito, P., \& Styawati, S. (2020). SISTEM PENDUKUNG KEPUTUSAN PEMBERIAN DANA BANTUAN MENGGUNAKAN METODE AHP. Jurnal Teknologi Dan Sistem Informasi, 1(2), 34-41.

Setiawansyah, S., Adrian, Q. J., \& Devija, R. N. (2021). Penerapan Sistem Informasi Administrasi Perpustakaan Menggunakan Model Desain User Experience. Jurnal Manajemen Informatika (JAMIKA), 11(1), 24-36.

Sihotang, H. T. (2018). Sistem pakar untuk mendiagnosa penyakit pada tanaman jagung dengan metode bayes. Journal Of Informatic Pelita Nusantara, 3(1).

Sulistiani, H., Darwis, D., Silaen, D. S. M., \& Marlyna, D. (2020). PENGEMB ANGAN MEDIA PEMBELAJARAN AKUNTANSI BERBASIS MULTIMEDIA (STUDI KASUS: SMA BINA MULYA GADING REJO, PRINGSEWU). Jurnal Komputer Dan Informatika, 15(1), 127-136.

Sulistiani, H., \& Muludi, K. (2018). Penerapan Metode Certainty Factor Dalam Mendeteksi Penyakit Tanaman Karet. Jurnal Pendidikan Teknologi Dan Kejuruan, 15(1), 51-59. https://doi.org/10.23887/jptk-undiksha.v15i1.13021

Sulistiani, H., Octriana, S., \& Adrian, Q. J. (2020). SISTEM PENGENDALIAN INTERN SIMPAN PINJAM ANGGOTA KOPERASI BMT (STUDI KASUS: BMT SYARI'AH MAKMUR). Journal of Social Sciences and Technology for Community Service (JSSTCS), 1(2).

Sulistiani, H., Sulistiyawati, A., \& Hajizah, A. (2021). Perancangan Sistem Pengelolaan Keuangan Komite Menggunakan Web Engineering (Studi Kasus: SMK Negeri 1 Gedong Tataan). Komputika: Jurnal Sistem Komputer, 10(2), $163-171$.

Sulistiani, H., Yuliani, A., \& Hamidy, F. (2021). Perancangan Sistem Informasi Akuntansi Upah Lembur Karyawan Menggunakan Extreme Programming. Technomedia Journal, 6(01 Agustus).

Syarifudin, A., Hidayat, N., \& Fanani, L. (2018). Sistem Pakar Diagnosis Penyakit Pada Tanaman Jagung Menggunakan Metode Naive Bayes Berbasis Android. Jurnal Pengembangan Teknologi Informasi Dan Ilmu Komputer, e-ISSN, $2738-2744$.

Wibisono, A. D., Rizkiono, S. D., \& Wantoro, A. (2020). Filtering Spam Email Menggunakan Metode Naive Bayes. Telefortech: Journal Of Telematics And Information Technology, 1(1), 9-17. 